\title{
PENERAPAN TEKNOLOGI TEPAT GUNA DALAM PRODUKSI DAN PEMASARAN USAHA BETUTU KHAS BALI DI BANJAR MAWANG KAJA, UBUD, GIANYAR
}

\author{
I Ketut Parnata ${ }^{*}$, Luh Mei Wahyuni², I Gde Agus Jaya Sadguna ${ }^{3}$ \\ dan Ni Luh Ayu Kartika Yuniastari Sarja ${ }^{4}$ \\ ${ }^{1,2}$ Akuntansi, Politeknik Negeri Bali \\ ${ }^{3,4}$ Pariwisata, Politeknik Negeri Bali \\ E-mail: iketutparnata@pnb.ac.id
}

\begin{abstract}
ABSTRAK. Pengabdian masyarakat dilakukan oleh perguruan tinggi dalam upaya untuk menerapkan teknologi tepat guna yang dihasilkan dari pengembangan keilmuan untuk masyarakat. Politeknik Negeri Bali pun melalui kegiatan pengabdian masyarakat yang dilakukan oleh para Dosen berkolaborasi dengan mahasiswa sudah seyogyanya membantu UMKM yang terdampak Covid-19 ini. Rai Kajol merupakan mitra dalam kegiatan ini yang berlokasi di Banjar Mawangkaja, Lodtunduh, Ubud. Rai Kajol memproduksi betutu khas Bali dan ayam panggang. Kendala yang dihadapi mitra saat ini adalah peralatan yang digunakan masih terbatas, sehingga memerlukan waktu lama untuk memproduksi dalam skala besar, pemasaran produk masih bersifat konvensional sehingga pelanggan terbatas pada konsumen disekitaran tempat usaha. Berdasarkan permasalahan yang dihadapi, maka akan dilakukan kegiatan terkait manajemen produksi dan pemasaran khususnya pemasraan online. Kegiatan dimulai dengan sosialisasi, pemberian peralatan yang menunjang produksi seperti mesin penghancur bumbu, alat pemanggangan, presto, pemberian bantuan label kemasan dan pelatihan pengemasan serta labeling kemasan, pembuatan media sosial dan pelatihan penggunaan media sosial. Indikator capaian adalah peningkatan jumlah produksi dan efisiensi waktu produksi. kemasan produk yang menarik dan ramah lingkungan, peningkatan pasar produk. Berdasarkan hasil evaluasi didapatkan dengan adanya penambahan alat produksi dapat mempercepat proses produksi, meningkatkan jumlah produksi dan menambah varian produk usaha mitra. Dari segi pemasaran, terdapat pelanggan baru dengan pemasaran menggunakan media online.
\end{abstract}

Kata kunci: Betutu; Teknologi Tepat Guna; Produksi; Pemasaran

ABSTRACT. Community service is carried out by universities to apply appropriate technology resulting from scientific development for the community. Even the Bali State Polytechnic, through community service activities carried out by lecturers in collaboration with students, should help SMEs affected by Covid-19. Rai Kajol is a partner in this activity which is located in Banjar Mawangkaja, Lodtunduh, Ubud. Rai Kajol produces Balinese betutu and grilled chicken. The obstacles faced by partners today are the equipment used is still limited, so it takes a long time to produce on a large scale, product marketing is still conventional so that customers are limited to consumers around the place of business. Based on the problems faced, activities related to production management and marketing will be carried out, especially online marketing. The activity started with socialization, providing production-supporting equipment such as a spice crusher, roasting equipment, pressure cooker, providing packaging label assistance and training on packaging and packaging labeling, making social media, and training on the use of social media. The indicators of achievement are the increase in the amount of production and the efficiency of production time. attractive and environmentally friendly product packaging, product-market enhancement. Based on the results of the evaluation, it was found that the addition of production equipment can speed up the production process, increase the amount of production and add variants of partner business products. In terms of marketing, there are new customers by marketing using online media.

Keywords: Betutu; Appropriate technology; Production; Marketing

\section{PENDAHULUAN}

Pengabdian masyarakat merupakan salah satu dari dharma pada tri dharma peguruan tinggi. Pengabdian masyarakat dilakukan oleh perguruan tinggi dalam upaya untuk menerapkan teknologi tepat guna yang dihasilkan dari pengembangan keilmuan untuk masyarakat. Politeknik Negeri Bali merupakan salah satu perguruan tinggi vokasi yang secara rutin melakukan kegiatan pengabdian masyarakat baik pendampingan pada Desa, Usaha Mikro Kecil Menengah (UMKM), institusi pendidikan, instansi pemerintahan dan kelompok masyarakat lainnya. Hal ini dilakukan sebagai wujud nyata visi yang di emban oleh Pusat Penelitian dan Pengabdian kepada
Masyarakat (P3M) Politeknik Negeri Bali dalam kaitannya dengan pemberdayaan masyarakat untuk peningkatan kesejahteraan masyarakat.

Pandemi Covid-19 berdampak sangat besar khususnya untuk provinsi Bali dimana pendapatan daerah sebagian besar berasal dari sektor pariwisata. Menurut Kepala BPS Bali Adi Nugroho melalui pemaparan daring, perekonomian Bali menghadapi penurunan yang dalam. Penurunan dua digit ini sejarah pertama yang dialami (https://bali.bisnis. $\mathrm{com} / \mathrm{read} / 20200805 / 538 / 1275290 /$ ekonomi-balisemester-i2020-terjun-akibat-pandemi-covid-19). Masyarakat Bali yang bekerja pada sektor pariwisata ataupun sektor lainnya yang terkena dampak pandemi ini banyak kehilangan pekerjaan dikarenakan 
perusahaan melakukan Pemutusan Hubungan Kerja (PHK). Masyarakat yang terkena PHK ini pun berusaha bertahan hidup dengan mulai membuka usaha baik industri rumah tangga maupun usaha kecil. Politeknik Negeri Bali pun melalui kegiatan pengabdian masyarakat yang dilakukan oleh para Dosen berkolaborasi dengan mahasiswa sudah seyogyanya membantu UMKM yang terdampak Covid-19 ini.

Rai Kajol merupakan mitra dalam kegiatan ini. Lokasi mitra berada pada Banjar Mawangkaja, Lodtunduh, Ubud. Bapak I Made Rai Sukanata merupakan pemilik usaha Rai Kajol yang memproduksi betutu khas Bali dan ayam panggang. Bapak Rai Sukanata pada awalnya merupakan chef atau koki pada salah satu restoran yang tutup dikarenakan pandemi Covid-19 ini. Bapak Rai Sukanata yang mengalami PHK mulai membuka usaha Betutu khas Bali untuk menyambung hidup. Alasan mitra memulai usaha betutu khas Bali ini adalah membantu tetangga maupun kenalan menyediakan ayam yang digunakan pada upacara yadnya. Pada awalnya betutu difungsikan sebagai diplomasi kedalam, yakni sebagai sarana persembahan terhadap Ida Hyang Widhi Wasa melalui upacara Dewa Yadnya. Namun selanjutnya dipersembahkan juga untuk kelengkapan Yadnya yang lain seperti Pitra Yadnya, Buta Yadnya, Rsi Yadnya, dan Manusa Yadnya, sehingga tidak mengherankan betutu memiliki fungsi religius,dan sosial (Purna \& Dwikayana, 2019). Betutu pun telah dikenal sebagai kuliner khas Bali oleh masyarakat luar daerah (Suardani, 2013). Berdasarkan promosi dari mulut ke mulut, mitra pun mendapatkan banyak pesanan dari konsumen baik untuk digunakan pada saat upacara persembahyangan maupun untuk acara lainnya. Mitra pun menambah varian produknya berupa ayam panggang dan produk ini pun banyak digemari konsumen. Saat ini mitra dibantu oleh 4 orang karyawan pada usahanya dalam memproduksi dan mengirimkan produk ke konsumen. Hingga saat ini usaha mitra masih bertahan dan tetap mendapatkan pesanan dari konsumen yang merupakan pelanggan tetap maupun konsumen baru. Pada saat hari raya, pesanan dari konsumen mengalami peningkatan sehingga mitra merasa kewalahan dikarenakan keterbatasan peralatan yang dimiliki. Proses produksi mitra menggunakan peralatan yang terbatas seperti kompor, panci, blender bumbu, mesin parutan kelapa dan penggorengan.

Omset usaha mitra tidak menentu bergantung pada pesanan dan hari raya. Penjualan rata-rata per bulan sekitar Rp. 3.000.000 - Rp 5.000.000. Apabila menjelang hari raya besar, maka penghasilan meningkat. Hal ini disebabkan ayam betutu maupun ayam panggang umum digunakan pada banten atau upakara pada saat hari raya. Pemasaran produk ayam betutu khas Bali dan ayam panggang masih bersifat konvensional yaitu pemasaran dari mulut ke mulut. Kemasan produk menggunakan kotak mika dan tanpa menggunakan label.

Beberapa permasalahan mitra dapat dijelaskan sebagai berikut :

1. Pendapatan mitra tidak menentu dipengaruhi oleh hari raya dan hanya mengandalkan pesanan dari konsumen.

2. Peralatan yang digunakan masih terbatas, sehingga memerlukan waktu lama untuk memproduksi dalam skala besar.

3. Pemasaran produk masih bersifat konvensional dan belum memanfaatkan teknologi sehingga pelanggan terbatas pada konsumen disekitaran tempat usaha.

4. Kemasan produk hanya kotak mika dan tidak berisi label kemasan sehingga kurang menarik.

\section{METODE}

Metode pelaksanaan dari kegiatan ini adalah wawancara, focus group discussion, pelatihan dan pendampingan. Tahapan kegiatan dimulai sosialisasi kegiatan, peningkatan alat produksi, pengemasan yang menarik, manajemen pemasaran, serta evaluasi kegiatan. Masing-masing tahapan yang dilakukan dalam kegiatan pengabdian masyarakat ini dapat dijelaskan sebagai berikut :

1. Sosialisasi dilaksanakan dengan mengadakan pertemuan antara tim dan mitra. Sosialisasi dilakukan agar terjadi persamaan pemikiran dan persepsi mengenai kegiatan yang akan dilakukan, dalam hal ini tim menyampaikan secara detail tahapan kegiatan, target dan tujuan dari pengabdian masyarakat ini.

2. Pemberian alat produksi yang dapat mempercepat dan meningkatkan jumlah produksi yaitu mesin penghalus bumbu, alat pemanggangan, kompor, panci besar dan panci presto.

3. Pemberian label kemasan produk yang berisi informasi mengenai produk dan informasi usaha dan kemasan ramah lingkungan berupa kemasan besek bambu. Untuk mewujudkan kemasan yang menarik, maka diadakan pelatihan labeling kemasan dengan memanfaatkan bantuan komputer dalam desain kemasan.

4. Pelatihan dan penyuluhan mengenai pentingnya manajemen pemasaran, khususnya pemasaran online. Selain itu dilakukan pelatihan mengenai pemanfaatan sosial media seperti facebook dan instagram untuk memasarkan produk.

5. Evaluasi kegiatan dilakukan untuk mengukur efektivitas dari program pengabdian masyarakat ini. Selain itu evaluasi dilakukan untuk mengukur pencapaian dari target luaran tim pengusul. 


\section{HASIL DAN PEMBAHASAN}

Untuk mengatasi permasalahan mitra maka kegiatan yang dilakukan adalah sebagai berikut.

1. Sosialisasi Kegiatan

Sosialisasi pada kegiatan dilaksanakan pada usaha mitra. Materi sosialiasi diberikan oleh I Ketut Parnata selaku ketua pelaksana beserta tim. Peserta adalah pemilik dan pegawai mitra kegiatan ini. Pada kegiatan sosialiasi disampaikan hal berupa latar belakang, target, sasaran dan tujuan kegiatan. Selain itu pelaksana kegiatan menyampaikan jadwal kegiatan pengabdian yang akan dilakukan.

2. Penyerahan Alat Produksi

Sesuai dengan kebutuhan mitra dalam hal produksi maka diberikan bantuan alat berupa mesin penghancur bumbu, alat pemanggangan, kompor, panci presto dan panci besar sehingga mempercepat proses produksi sehingga dapat digunakan untuk memproduksi ayam betutu dalam dalam jumlah lebih banyak. Selain itu untuk mendukung program pemerintah mengurangi sampah plastik, maka di buat kemasan ramah lingkungan berupa kemasan menggunakan besek dan labeling kemasan. Bantuan kemasan produk ini agar menambah nilai jual dari ayam betutu maupun ayam panggang. Penyerahan alat bantu produksi dan kemasan dilakukan pada lokasi usaha mitra.

3. Pembuatan Desain Labeling Kemasan dan Pelatihan Pengemasan

Untuk membuat produk lebih menarik dan meningkatkan nilai jual, diperlukan label kemasan yang didesain untuk produk betutu dan ayam panggang. Selain itu untuk memperluas pemasaran, labeling kemasan digunakan sebagai media informasi kepada customer. Label produk yang didesain akan memuat informasi mengenai nama usaha dan contact. Desain label Rai Kajol dapat dilihat pada Gambar 1.

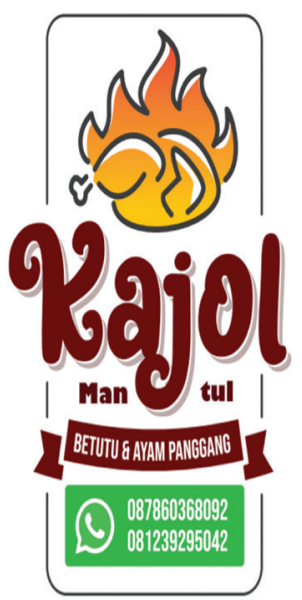

Gambar 1. Desain label kemasan
Selain itu di pula kemasan dari bahan bambu (besek) dibuar agar lebih ramah lingkungan dan mengurangi sampah plastik. Dokumentasi pelatihan labeling kemasan dapat dilihat pada Gambar 2.

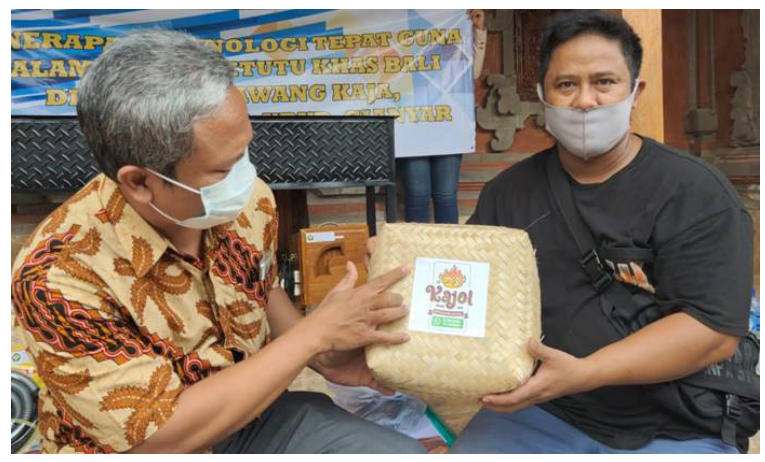

Gambar 2. Pelatihan pengemasan produk betutu

\section{Pelatihan Pemasaran Online}

Pemasaran merupakan aspek penting dalam pengelolaanusahauntukmembantumeningkatkan penjualan. Selain itu untuk meningkatkan daya saing produk, banyak UMKM memanfaatkan bantuan teknologi informasi dalam memasarkan produk sehingga produk lebih dikenal di masyarakat dan pemasaran lebih luas. Pada kegiatan ini, tim dan mitra menggunakan media sosial untuk memasarkan produk. Media sosial yang digunakan adalah facebook dan Instagram. Mitra sudah cukup familiar dengan penggunaan teknologi informasi sehingga dapat dengan mudah memahami materi dalam pelatihan media sosial ini Untuk media promosi dan informasi mengenai usaha mitra, serta mempermudah customer menemukan lokasi mitra, maka diberikan bantuan plang nama yang akan dipasang pada lokasi mitra.

5. Monitoring dan Evaluasi Kegiatan

Monitoring dan evaluasi kegiatan dilaksanakan dua kali yaitu pada saat pertengahan kegiatan dan akhir kegiatan. Monitoring dan evaluasi tahap pertama dilakukan dengan wawancara kepada mitra. Berdasarkan hasil wawancara, kegiatan penambahan alat produksi seperti mesin penghalus bumbu, presto dan alat pemanggangan mempercepat proses produksi dan menghasilkan jenis produk baru yang diproduksi mitra yaitu sate lilit ayam, telur pindang, bebek betutu dan bebek panggang. Hal ini menambah varian produk yang dijual oleh mitra. Selain itu proses presto dan pemanggangan yang awalnya dilakukan berkalikali dengan kapasitas alat produksi skala kecil, saat ini dapat dilakukan hanya 1-2 kali. Berdasarkan evaluasi dari segi pemasaran, dengan pemasaran menggunakan media online terdapat pelanggan baru dan mitra telah menggunakan media online untuk memasarkan produk dan beberapa pesanan dari customer yang diunggah pada media sosial oleh mitra. Untuk monitoring dan evaluasi tahap 
kedua Evaluasi dilakukan untuk mengetahui ketercapaian luaran dengan indikator yang telah ditetapkan. Hasil evaluasi menunjukkan dengan adanya peningkatan alat produksi berdampak signifikan pada waktu produksi yang berkurang $66 \%$ serta peningkatan jumlah produksi. Adanya pelatihan pengemansan, capaian $100 \%$ produk berisi label kemasan tercapai.

\section{SIMPULAN}

Berdasarkan kegiatan yang telah dilakukan sampai saat ini maka diperoleh beberapa kesimpulan, yaitu:

1. Kegiatan yang telah dilakukan sampai saat ini oleh Tim Pengabdian bersama-sama dengan mitra antara lain: kegiatan sosialisasi, penyerahan alat produksi, pembuatan desain labeling kemasan dan pengemasan, pelatihan media pemasaran online, serta monitoring dan evaluasi kegiatan.

2. Berdasarkan hasil evaluasi, tahap pertama didapatkan dengan adanya penambahan alat produksi mempercepat proses produksi dan menambah varian produk usaha mitra. Dari segi pemasaran, dengan pemasaran menggunakan media online terdapat pelanggan baru dan mitra telah menggunakan media online untuk memasarkan produk.

\section{UCAPAN TERIMAKASIH}

Pengabdian kepada masyarakat ini terlaksana berkat bantuan pendanaan dari Politeknik Negeri Bali. Terimakasih kami ucapkan kepada Politeknik Negeri Bali atas dukungannya. Serta terimakasih kepada Mitra, Rai Kajol yang telah bekerja sama dalam kegiatan pengabdian ini.

\section{DAFTAR PUSTAKA}

Gurnelius, S. (2011). 30-minute Sosial Media Marketing. USA: McGrawHill Co

Hendratman, H. (2016) : The Magic of Adobe Photoshop. Bandung : Informatika

Kristianto, F. 2020. Ekonomi Bali Semester I-2020 'Terjun' Akibat Pandemi Covid-19. https:// bali.bisnis.com/read/20200805/538/1275290/ ekonomi-bali-semester-i-2020-terjun-akibatpandemi-covid-19) diakses 10 Februari 2021.

Purna, I.M., Dwikayana,K. (2019). Betutu Bali : Menuju Kuliner Diplomasi Budaya Indonesia. Patanjala, 9(2), 265-280.

Suardani, M. (2013). Analisis Keputusan Pengunjung Membeli Ayam Betutu Pada Rumah Makan Ayam Betutu Khas Gilimanuk Di Tuban Bali. Soshum Jurnal Sosial Dan Humaniora, 3 (2), 151-163 